\title{
Industrial Network Membership: reducing psychic distance hazards in internationalization of firms
}

\author{
Pertencer a Redes Industriais: reduzindo os efeitos da distância psíquica na \\ internacionalização da empresa
}

Pertenencia a la Red Industrial: reduciendo los riesgos de la distancia psíquica en la internacionalización de la empresa

\author{
João Carvalho Santos ${ }^{1}$ \\ Manuel Portugal Ferreira ${ }^{2}$ \\ Nuno Manuel Rosa dos Reis ${ }^{3}$
}

Recebido em 23 de setembro de 2011 / Aprovado em 05 de dezembro de 2012

Editor Responsável: João Maurício Gama Boaventura, Dr.

Processo de Avaliação: Double Blind Review

\begin{abstract}
The network approach to internationalization of firms has been the research focus of many international business scholars. Firms are increasingly involved in international business ventures and arguably need to learn to adapt to the idiosyncratic milieus of foreign markets. This paper proposes a conceptual model suggesting that integration in industrial networks strengthens corporate competitiveness in international markets. Network membership provides access to knowledge and a wider array of physical, technical, reputational and financial resources that facilitate
\end{abstract}

adaptation to the various dimensions - economic, political, legal, cultural - of international business environments. Membership in social and business networks is likely to ease internationalization by reducing the psychic distance perceived by firms.

Key words: Networks. Internationalization theories. Psychic distance.

\section{RESUMO}

A perspectiva da teoria de redes sobre a internacionalização das empresas foi escolhida por diversos

1. Doutorando em Gestão na Faculdade de Economia, Universidade do Porto, Portugal. Professor do Instituto Politécnico de Leiria e Membro do Centro de Investigação globADVANTAGE - Center of Research in International Business \& Strategy. [joao.santos@ipleiria.pt]

2. Doutor em Business Administration pela David Eccles School of Business da Universidade de Utah, EUA. Professor do Instituto Politécnico de Leiria e Diretor do Centro de Investigação globADVANTAGE - Center of Research in International Business \& Strategy. [manuel.portugal.ferreira@gmail.com]

3. Doutorando em Gestão na Universidade de Coimbra, Faculdade de Economia, Portugal. Professor do Instituto Politécnico de Leiria e Membro do Centro de Investigação globADVANTAGE - Center of Research in International Business \& Strategy. [nuno.m.reis@ipleiria.pt]

Endereço dos autores: Morro do Lena - Alto do Vieiro - 2411 - 901 Leiria, Portugal 
autores de negócios internacionais para sua pesquisa. As empresas estão cada vez mais envolvidas em operaçóes internacionais e precisam aprender a se adaptar aos meios idiossincráticos que encontram nos mercados internacionais. Este artigo propóe um modelo conceptual que sugere que a integração em redes industriais aumenta a competitividade nos mercados internacionais. A integração em uma rede permite aceder a conhecimento e a um conjunto alargado de recursos físicos, técnicos, financeiros e de reputação que facilitam a adaptação às várias dimensóes - econômica, política, legal, cultural - dos ambientes internacionais de negócios. A integração em redes sociais e de negócios pode facilitar a internacionalização ao reduzir a distância psíquica percebida das empresas.

Palavras-chave: Redes. Teorias da internacionalização. Distância psíquica.

\section{RESUMEN}

La aproximación de la red hacia la internacionalización de las empresas ha sido el eje de la investigación de muchos académicos de negocios internacionales. Las empresas están cada vez más involucradas en los esfuerzos de negociación internacional y puede decirse que necesitan aprender a adaptarse a idiosincrasias del medio que encuentran en los mercados extranjeros. Este artículo propone un modelo conceptual que estipula que la integración en las redes industriales refuerza la competitividad corporativa en los mercados internacionales. Ser miembro de una red proporciona acceso al conocimiento y a una serie más amplia de recursos físicos, técnicos, de reputación y financieros que facilitan la adaptación en sus diferentes dimensiones - económica, política, legal, cultural - del entorno internacional de los negocios. Es probable que la pertenencia como miembro a las redes sociales y de negocios facilite la internacionalización a través de la reducción de la distancia psíquica percibida por las empresas.

Palabras clave: Redes. Teorías de la internacionalización. Distancia psíquica.

\section{INTRODUCTION}

The increasing globalization of markets and production, most prominent in the last three decades, has led to multiple challenges for firms, namely for those that need to internationalize, but lack experience in foreign markets or in conducting international operations. The gradual decrease of both traditional trade and investment barriers and of transportation costs has enlarged the national (or domestic) markets, which are opening up to all sorts of foreign competitors (BUCKLEY; CASSON, 1998) and these challenge local players within their national and previously protective borders. That means that firms need to reconsider their strategies at a global level, including choices regarding which markets to enter and the best locations for each stage of the value chain (AULAKH; TEEGEN; KOTABE, 2000) to improve their competitive capacity. Governments and policy makers face the challenge of how to foster firms' competitiveness, which may include actions to improve infrastructure, education and $\mathrm{R} \& \mathrm{D}$, but also policies promoting a wide range of strategically crafted partnerships among firms.

The internationalization of firms may be considered as an incremental process. Initially, firms select markets that are psychologically less distant, which allows them to gain experience in international operations (JOHANSON; VAHLNE, 1977; BOUTHERS; HENNART, 2007). Johanson and Wiedersheim-Paul (1975) argued that uncertainty about foreign markets is related to the psychic distance between home and host country. Psychic distance (PD) is "the result of factors that prevent or hinder the flow of information between firms and the market" (JOHANSON; WIEDERSHEIM-PAUL, 1975, p. 307), or put differently, PD is the lack of knowledge of foreign market features (KOGUT; SINGH, 1988). PD results in many unanswered questions concerning not only the transferability of market-specific knowledge, but also the degree of efficacy in transferring knowledge internally to subsidiaries, where it could be put into productive use (WANG; TONG; KOH, 2004; MINBAEVA, 
2007). Other questions relate to the actual sources of competitive advantages which, at least in some instances, may be embedded in firm-specific resources (BARNEY, 1991; MINBAEVA, 2007). In any case, firms may circumvent potential difficulties and hazards by partnering with others. Those partnerships may point out an array of market opportunities but they may also be more effective vehicles to identify and capture new knowledge. Firms arguably reduce the perceived uncertainties of carrying out foreign operations by integrating networks along with domestic firms. Integration in a network is likely to strengthen the competitiveness of firms in international markets (BRADLEY; MEYER; GAO, 2006). The network membership provides a variety of benefits that range from access to legitimacy (FORD et al., 2002; JOHANSON; VAHLNE, 2009), financial and technical resources (GADDE; FORD, 2008) and flows of technical and of market-specific knowledge (FURLAN; GRANDINETTI; CAMPAGNOLO, 2009) which may reduce possible hazardous effects of psychic distance. A network is a structure in which multiple nodes are connected to each other by specific relationships (HAKANSSON; FORD, 2002) and it consists of firms and the relationships between them (FORD et al., 2003). According to the network theory, the individual firms rely on other firms for access to resources (JOHANSON; MATTSSON, 1988; AXELSSON; EASTON, 1992). Following Elo (2005), we use the term industry network to reflect the "longterm relationships between legally independent companies that exploit mutual complementarities and exchange information / knowledge".

Although there is research on the effect of $P D$ and networks in the internationalization of firms (BLANKENBURG; ERIKSSON; JOHANSON, 1996; CHETTY; BLANKENBURG, 2000), it is not clear whether and how firm network membership reduces the effects of PD in internationalization of firms. This paper contributes to the discussion on how firms' membership in industrial networks is likely to decrease the effects of psychic distance - thus improving their competitiveness and performance in foreign markets - by proposing a conceptual model that scrutinizes the network benefits related to the perceived psychic distance. Firms need to engage in a continuous innovation process and constantly restructure their operations to meet the requirements of international competition. Failure to act internationally may lead to a loss of market opportunities, but also to a more severe inability to survive in the long run (GHEMAWAT, 2001, 2007). Firms must find new ways to develop a competitive advantage (PORTER, 1980) which entails searching for and acquiring new skills, resources and capabilities (BARNEY, 1991). Knowledge is an important strategic resource (WERNERFELT, 1984; PETERAF, 1993) due to its impact on firms' competitive capacity. In many instances, firms may access those resources, including the market-specific knowledge, through alternative ways of governance, such as industrial networks' (NOHRIA; GHOSHAL, 1997). In fact, firms seem to gain international competitiveness by integrating 'industrial networks'. Integrating a network may facilitate access to market-specific knowledge that an isolated firm would not be able to get hold of otherwise.

This paper is organized in four main parts. First, we present some different perspectives of internationalization theories. Second, we specifically review the extant literature on the concept of industrial networks and psychic distance. Third, we put forward a conceptual model scrutinizing the network benefits in relation to the perceived psychic distance when firms internationalize. We conclude with a broad discussion and by pointing out implications and avenues for future inquiry.

\section{INTERNATIONALIZATION: DIFFERENT PERSPECTIVES}

A wealth of research has addressed the internationalization of firms under various theories and different perspectives. An extensive review is largely beyond our immediate scope, but it is worth noting that some explanations for the internationalization of firms are founded on increased market power (HYMER, 1976), the internalization 
theory (BUCKLEY; CASSON, 1976), the international product life cycle (VERNON, 1966), the eclectic paradigm (DUNNING, 1988) and the transaction costs theory (HENNART, 1988). Other perspectives include internationalization as a process that depends on factors such as attitudes, perceptions and behavior of managers (ANDERSEN; BUVIK, 2002) and internationalization as a sequential and evolutionary process (JOHANSON; WIEDERSHEIM-PAUL, 1975; JOHANSON; VAHLNE, 1977; 1990; 2006; 2009). Also noteworthy are the explanations based on the network theory and network concepts (FORD, 1980; HAKANSSON, 1982; HAKANSSON; JOHANSON, 1984; 1992).

The theory of internationalization in stages, or the Uppsala evolutionary model, was developed by Johanson and Wiedersheim-Paul (1975), Johanson and Vahlne (1977) and later revisited by Johanson and Vahlne (2009). The evolutionary model advances that internationalization is a gradual process. It explains how firms accumulate knowledge on the foreign markets and how they operate internationally. According to Johanson and Wiedersheim-Paul (1975), internationalization is a gradual process due to the psychic distance or the differences between countries that cause uncertainty (CAVUSGIL; ZOU, 1994). Firms seek to minimize uncertainties by entering initially closer countries (proximity evaluated as to the economic and cultural profile and the geographic distance) and, as they gain experience, move to more distant countries. Similarly, when entering unchartered territories, firms prefer to do so using low involvement/low investment modes and as they gain knowledge of those markets, evolve to more investment-intensive entry modes (JOHANSON; WIEDERSHEIMPAUL, 1975; JOHANSON; VAHLNE, 1977). This theory is not undisputed as it has received a great deal of criticism. For instance, critics argued that since the 1970's the environment changed and has led firms to modify their behaviors, thus making psychic distance less important (MADSEN; SERVAIS, 1997). On the other hand, alternative approaches to internationalization have since emerged, such as the ideas on born global firms (OVIATT; MCDOUGALL, 1994; MADSEN;
SERVAIS, 1997), which don't follow the prescriptive evolutionary process of the Uppsala school. Notwithstanding, Johanson and Valhne (2009) argued that born global firms are in fact "born regionals" since most of them feature only regional rather than global operations (JOHANSON; WIEDERSHEIM-PAUL, 1975), which suggests that there is still a rather progressive path of internationalization, from closer to more distant geographies.

In the revised version of the Uppsala model, Johanson and Vahlne (2006; 2009) explicitly acknowledge the importance of belonging to networks to select and enter a market, although this effect was already implicit in the original model. Relationship building in a network is a bilateral process by which both parts interactively learn and develop mutual commitment and trust. The relationships inside a network allow firms to access knowledge, resources and capabilities of other network members identified as "insidership" (JOHANSON; VAHLNE, 2009). Firms not belonging to a network have to face additional challenges when internationalizing, which the authors termed "liability of outsidership". Outsidership hinders the exploitation of opportunities due to reasons like lack of information and of strategic resources and capabilities (JOHANSON; VAHLNE, 2009). That effect was already implicit in the original model but the authors explicitly acknowledge its importance in the 2009 revision. In sum, the implicit proposition in the extant research might be formulated as follows: the largest the perceived psychic distance of home and host country, the riskier the performance in the foreign market and the more firms prefer to mitigate the risks involved through low involvement entry modes.

Arguably more notable have been the approaches on internationalization based on market imperfections and on the internalization theory developed by Buckley and Casson (1976), positing that firms should internalize their activities, both in national and international markets, when the free market is less efficient and / or more expensive (RUGMAN, 1981). The more recent emphasis on the resources held 
explains internationalization as a way of exploiting the firms' competitive advantages in foreign markets (BUCKLEY; CASSON, 1976). The envelope paradigm constructed by John Dunning $(1977,1981,1988)$ - the Eclectic paradigm - is a framework used to rationalize on the decision to internationalize, and how to do it, requiring that we examine three core dimensions: ownership, location and internalization advantages. In a subsequent revisitation of the eclectic paradigm, the institutional dimension was included in the components of the OLI model (DUNNING; LUNDAN, 2008). The importance of networks is not overlooked by Dunning in the OLI model. Dunning (1995; 2011) noted how increasingly important the interfirm modes of cooperation are, be it using strategic alliances, networks or other hybrid forms of governance. Furthermore, Dunning (2011) argued that learning and knowledge may be considered market imperfections that must be overcome. Thus, network membership and other cooperative modes may allow firms to deal with such market imperfections (DUNNING, 2011).

The internationalization of firms based on network explanations are somewhat more recent and are founded on the core idea that firms have much to gain from partnering with others for both access to scale and scope resources, but also to gain knowledge on the markets (WEISFELDER, 2001). In fact, according to Johanson and Mattson (1988), network membership is compulsory for businesses - as strategic resources are increasingly scarce and firms in isolation are unable to hold a pool of resources that may render them competitive. Johanson and Vahlne (1990) and Welch and Welch (1996) also posited that firms should be seen as embedded within a network of relationships and networks that may be unintentional or strategically planned (HITE; HESTERLY, 2001) - namely when entering foreign markets.

Although we may identify different theories explaining internalization, there are some facts in common. For instance, the Uppsala model (JOHANSON; VAHLNE, 1977) posits that firms exploit opportunities in countries closer to the home country, with similar country specific advantages (CSA) and eventually go to more distant markets to take advantage of firm specific advantages (FSA), such as network membership (JOHANSON; VAHLNE, 2009). On a different approach, Hennart (2009) considers that some CSAs are not available in the market and internationalizing firms are compelled to build partnerships with local actors that hold the needed CSAs. Therefore, both the Transaction Costs Theory (HENNART, 2009) and the revised version of the Uppsala model (JOHANSON; VAHLNE, 2009) acknowledge the importance of network membership to overcome the difficulties of entering a foreign market.

\section{I Network' supported internationalization}

The extant research has employed different terms to designate industrial networks, including networked organizations, organizational networks, inter-organizational networks, network businesses, networking among firms, network, networking, relationship network, networks of interorganizational networks, inter enterprises and enterprise networks. Regardless of the actual usage, a network refers to a set of business relationships, both horizontal and vertical, with other organizations - be they suppliers, customers, competitors, or other entities. According to Hakansson and Ford (2002) a network is a structure in which multiple nodes are connected to each other by specific relationships. The relationships are inter-organizational ties of strategic importance for the firms involved and may include strategic alliances (GULATI et al., 2000), as well as other "long-term relationships between legally independent companies that exploit mutual complementarities and exchange information / knowledge" (ELO, 2005). In these networks, each party carries out different activities and exchange valuable resources, based on cooperative trust relationships and an alignment of long-term interests (JOHANSON; MATTSSON, 1988; EASTON; HAKANSSON, 1996; FORD et al., 2002; JOHANSON; VAHLNE, 2009). For the interactions to last, 
there must be benefits for all parties involved (JOHANSON; WIEDERSHEIM-PAUL, 1975; JOHANSON; VAHLNE, 2006, 2009).

The industrial network theory describes the market as a social system where industrial relations link customers, suppliers, competitors, family, and friends. The nature of the relationships between the various parties influences the strategic decisions. One basic assumption of the industrial networks model is that individual firms depend on the resources controlled by other firms, either to obtain the needed inputs or to place outputs. Firms may only access these resources by establishing a position within the firm network (ANDERSEN; BUVIK, 2002).

Network research in international business studies has counted many contributions. Hakansson and Johanson (1984), for instance, put forward a model of industrial networks known as the ARA model (Actors-Resources-Activities) pointing out that the main actors in the internationalization process are the institutions, firms and individuals that interact to facilitate the exchange (HAKANSSON; JOHANSON, 1992). These actors include importers and exporters, financiers, government institutions and consultants, to name but a few. Their activities consist of the various forms of exchanges - direct and indirect - that occur between actors within the network. Direct activities affect the exchange process, as in the case of individual firms, while the latent and indirect links are derived from actions by governments and multilateral organizations. Another distinction of activities differentiates between processing activities where the resources, held by a particular actor, are altered in some way - and transfer activities where resources are shared by the actors (HAKANSSON; JOHANSON, 1992).

A core assumption in network theory is that individual firms have to rely on other firms for at least some of the needed resources and to gain access to those resources, firms must establish a position within the network (JOHANSON; MATTSSON, 1988; AXELSSON; EASTON, 1992; JOHANSON; VAHLNE, 2009). Network resources include, e.g., products, raw materials, information, different types of knowledge, capital and technology (JOHANSON; WIEDERSHEIMPAUL, 1975).

Networks may also be formed in an unplanned manner, whereby the knowledge acquired in the network and the development of the network itself may influence the manner and mode that firms chose to internationalize (WELCH; WELCH, 1996). The degree of internationalization of a firm reflects not only the resources allocated abroad, but also the degree of internationalization of the network in which the firm is inserted. Thus, internationalization is not just a matter of moving products or productions to foreign countries, but may be better understood as the exploitation and exploration of potential cross-border relationships (JOHANSON; VAHLNE, 1990, 2009, ANDERSSON; JOHANSON, 1997).

\subsection{Psychic distance and the internationalization of firms}

The internationalization of firms has been explained as an incremental process that may be depicted as following a sequence of phases. As firms internationalize, they accumulate experience, knowledge and proceed with higher commitment to investment in foreign markets (JOHANSON; VAHLNE, 1977). According to Johanson and Wiedersheim-Paul (1975), firms begin internationalizing in nearby markets markets in close geographic proximity, with cultural, political and legal systems that are similar to those found in the home country of the multinational (MNC). The initial expansion to proximate locations seeks to reduce the perceived risks by avoiding unfamiliar spaces and by selecting entry modes that require a low commitment of resources. The most common first foreign entry mode is therefore direct and indirect exports and as firms increase their internationalization, namely expanding to farther countries, they assume greater risks and deploy entry modes like acquisitions or greenfield startup ventures.

The first researcher referring to the concept of "psychic distance" (PD) was Beckerman, in 
1956, who highlighted the perceived distance between countries and the consequences for international trade. Trade between countries was not only determined by the physical distance between them, but also by other factors that create a sense of dissimilarity, such as language, culture and personal relationships between entrepreneurs (BECKERMAN, 1956). According to Johanson and Wiedersheim-Paul (1975, p. 307) psychic distance may be defined as "the result of factors that prevent or impede the flow of information between firms and the market" or, according to Johanson and Vahlne (1977, p. 24), as "the set of factors that impede the flow of information and the market". Psychic distance may also be defined as the degree of ignorance of a firm regarding the features of a foreign market (KOGUT; SINGH, 1988). According to Evans, Treadgold and Mavondo (2000a, 2000b), PD is the distance between the domestic and the foreign market that results from the perception and understanding of cultural differences and the negotiation between them. The construct of psychic distance is made up by a set of variables that make the environments of the home and host country differ, including such aspects as language, religion, level of economic development, wealth distribution, level of education, degree of technological sophistication, geographic distance, pervasiveness of corruption and cultural differences (JOHANSON; WIEDERSHEIMPAUL, 1975).

PD is posited to have an impact on the entry mode decision. A manager's choice of the entry mode in a foreign market in based on his perceptions of the environment, i.e., his perceptions of psychic distance (HARZING, 2003; SOUSA; BRADLEY, 2006, 2008). Specifically, a high degree of psychic distance between countries is expected to have a negative impact on a firm's need for high operational control on a foreign market (DOW; LARIMO, 2009). This negative impact has been supported by several empirical studies, which have found a significant negative correlation between PD and entry mode selection (ZHAO; LUO; SUH, 2004; MAGNUSSON et al., 2006).
Psychic distance has also been demonstrated to have an impact on performance (EVANS; TREADGOLD; MAVONDO, 2000b; EVANS; MAVONDO, 2002). Performance may be defined and measured in several different ways. For instance, financial indicators have been used to assess the influence of PD on corporate performance (EVANS; MAVONDO, 2002). Evans and Mavondo (2002) have also taken into account organizational performance and strategic effectiveness to evaluate the influence of PD. Other studies (e.g., GRIFFITH, 2011) have used combined measures of international performance, such as the EXPERF scale (ZOU; TAYLOR; OSLAND, 1998) which combines three dimensions - financial, strategic and satisfaction - of exports. Performance is therefore rather ambiguous and may encompass many different outcomes of corporate operations.

\section{CONCEPTUAL DEVELOPMENT}

Integration in a network is likely to strengthen the competitiveness of firms in international markets. Being a member of a network that features related and unrelated firms provides a variety of benefits, such as access to legitimacy (FORD et al., 2003), financial and technical resources (HITE; HESTERLY, 2001) and flows of technical and, perhaps more important, of market-specific knowledge (HAKANSSON; SNEHOTA, 2006) thus reducing possible hazardous PD effects.

We propose scrutinizing the network benefits regarding a specific impact - the impact on the perceived psychic distance - and advance a conceptual model, depicted in Figure 1 below.

Internationalization of firms occurs incrementally. Initially, firms select markets that are psychologically less distant to gain experience in international operations in general and in operations of that specific market. To minimize risks and gain knowledge about customers, suppliers, bureaucratic procedures, exchange rates, taxation, customs barriers, etc., firms first enter foreign markets through exports (JOHANSON; 


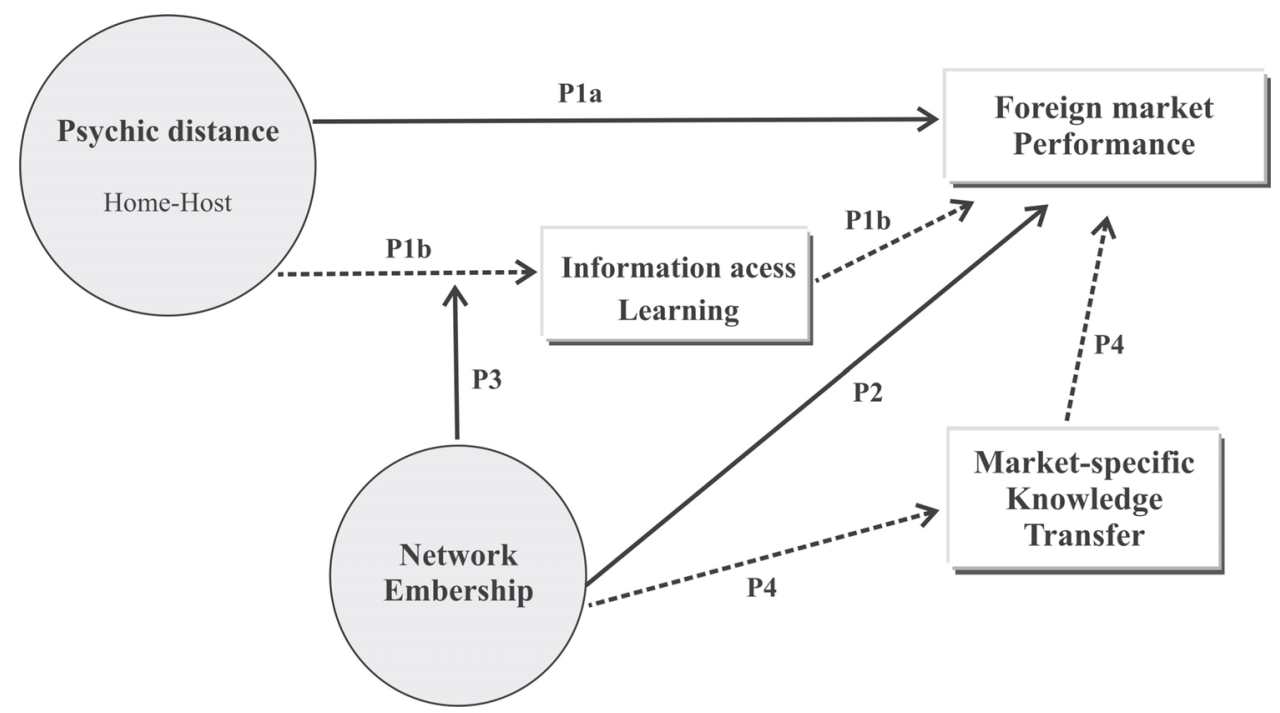

Figure 1 - Conceptual model.

Source: authors.

VAHLNE, 1977). As they accumulate knowledge on the market, they may become more involved using alternative modes, such as strategic alliances or joint ventures, and may even evolve deploying acquisitions or establishing greenfield subsidiaries in those countries.

Firms following an incremental internationalization process may do so as a manner to reduce uncertainty and potential hazardous effects. Vahlne and Wiedersheim-Paul (1975) argued that uncertainty about foreign markets is related to the psychic distance between home and host countries. For instance, the psychic distance between Brazil and any given foreign market is determined by a number of factors, such as the level of development, level of education, business language, cultural differences, language and relationships of many kinds between the country of origin and the host. The greater the difference between such factors, the greater the psychic distance between countries. A larger PD will arguably lead to greater uncertainty in operating in those countries (CARLSON, 1975; FORD, 1984). On the other hand, $\mathrm{PD}$ - i.e., differences in language, culture, bureaucratic issues, institutions, etc. - also has an impact on access to information and learning, which in turn influences corporate operations. A proposition advancing this dual effect may thus be specified as follows:
Proposition 1a. Psychic distance is likely to have a negative impact on corporate performance in foreign markets.

Proposition 1b. Psychic distance is likely to have a negative impact on corporate performance in foreign markets by hampering access to information and learning. In other words, psychic distance hampers access to information and learning, which in turn leads to reduced corporate performance.

When firms decide to internationalize, they need to make a set of decisions, namely on the market/country in which to operate and the mode. According to Ghemawat (2001) the decision to internationalize may be seen from two points of view. On one hand, considering the convergence of markets as a result of globalization (LEVITT, 1983), internationalization is nothing more than entering a new market that's already known, so the perceived risk is reduced. On the other hand, realizing that markets differ, the decision to internationalize a firm involves high risks and the need to adapt to an entire set of norms and rules that are different from those in the home country. To adapt, firms may require new skills and resources. To reduce the potential risks and hazards, firms initially choose to enter proximate markets and only join more 
distant markets at a later stage (JOHANSON; WIEDERSHEIM-PAUL, 1975).

Internationalization is an often recurring consequence of the growth process and is seen as an incremental process (HALLEN; WIEDERSHEIMPAUL, 1993). The speed and sequence of the internationalization process depend on the degree of knowledge on foreign markets (external environment), experience, etc. The degree of knowledge reduces the PD between the domestic and the external environment (JOHANSON; VAHLNE, 1977) and we believe that network membership contributes positively to attenuate those effects. Network membership provides small and medium firms with the know-how required to access foreign markets, increasing their chances to survive in international markets (BRADLEY et al., 2006). In sum, the gained knowledge seems to suggest a broad proposition:

Proposition 2. Network membership is likely to contribute positively to improved corporate performance in foreign operations.

Firms that are integrated in an industrial network may share and transfer market-specific knowledge in a more intense manner. Network membership (insidership) allows companies to learn about issues that would otherwise increase the PD (JOHANSON; VAHLNE, 2009). The hazards of PD are increased by outsidership - i.e., not belonging to a network - since firms don't have access to information (JOHANSON; VAHLNE, 2009). The sharing of knowledge and resources among network members is likely to reduce the possible PD effects for firms entering a new country. Reduced PD effects are obtained through information and knowledge on foreign markets shared among network members (NOHRIA; GHOSHAL, 1997), which may reasonably lead us to conclude that corporate performance should improve. Thus, our next proposition states:

Proposition 3. Industry network membership positively moderates the negative impact of psychic distance on corporate performance in a foreign market by promoting access to information and learning.

\section{INDUSTRIAL NETWORKS EFFECTS ON MARKET-SPECIFIC KNOWLEDGE TRANSFER}

Membership in industrial networks may be a way to better absorb market-specific knowledge. International knowledge transfer, even within a company, e.g., between the subsidiaries of a parent MNC, includes many aspects of the local cultures in which the subsidiaries operate. Hazards increase when firms operate in unfamiliar territories. In these instances, learning a priori about the foreign markets with the support of the network members is a viable manner to mitigate losses. Networks help to understand the prevailing cultural standards and practices (HAKANSSON; SNEHOTA, 2006).

A network is a set of exchange relations among firms that are linked by long-term relationships and joint interests or commonalities (COOK; EMERSON, 1978). However these relationships are in constant flux (JOHANSON; MATTSSON, 1988). Firms develop and/or change the relationships with their partners according to their objectives. E.g., if a firm wants to enter a new market, it has to establish new relationships and sometimes end others (HAKANSSON; SNEHOTA, 1995). The more integrated the company network, the fewer changes the firm has to make, because firms can trust their partners more.

The networks promote an environment that's conducive to sharing market-specific knowledge and resources, which allows firms to gain competitive advantages in both domestic and external markets. Unlike centralized and hierarchical management, which may not allow the exchange of information, firms that belong to industrial networks put particular emphasis on knowledge transfer between all partners/firms, including subsidiaries (NOHRIA; GHOSHAL, 1997). E.g., knowledge absorbed from local partners may be market-related, while the ties 
binding other firms may rely on technologyrelated knowledge transfer, labor practices, process-related best practices, $R \& D$ efforts, new distribution channels, etc. The ultimate purpose is to apply that market-specific knowledge to improve performance. In sum, we propose that network membership impacts knowledge transfer, noting that it is a crucial transfer - even if that knowledge refers to many different issues:

Proposition 4. Industry network membership is likely to positively impact company performance by promoting market-specific knowledge transfer among network members. In other words, network membership promotes more effective market knowledge transfer which, in turn, leads to improved company performance.

\section{DISCUSSION AND FINAL REMARKS}

Industrial networks play an important role in the internationalization of firms worldwide, as the increasing number of published articles on the topic confirms (FORD et al., 2002). Networks provide firms with an array of resources and market- and client-related information, improving the odds of survival and success. In addition to that, networks may be intentionally and strategically constructed so as to serve the company goals at a specific time. Due to their facilitating role, there has been a lot of research on network influence in international business literature.

Firms construct industrial networks to reduce the barriers and hazards faced before, during and after internationalization and managers are in charge of identifying opportunities to integrate networks, which networks to join and which to leave. The success of each firm in the network is the result of the conduct of all firms in the network (TORNROOS, 2002, 2004), which requires that managers have to pay attention to the evolution and performance of the network they belong to.

Understanding the importance of the network is relevant for both internationally inexperienced as well as multinational corporations.
Network contacts allow firms to access resources they lack and that they could not access otherwise, i.e., through internal development. It is also interesting to consider network membership as a manner to reduce the exposure of firms to unchartered countries. Using network contacts, firms may avoid employing other entry modes that involve greater risks. In fact, the network membership may be seen as an alternative entry mode that may be added to the pool of available strategies. Arguably, networks may be of even greater interest for small and medium companies that lack the human, technical and financial resources to undertake internationalization alone.

In terms of theory, network research may offer avenues that have been underexplored. It is now recurrently referred to that firms should focus on their core competences and core business. All activities that don't belong to the core and that aren't of strategic importance may be outsourced in the factor market. Indeed, firms may use this rationale when selecting and constructing their networks. The value of a network depends on the time and on the medium and long term strategy for a specific market. Future research could explore how firms are reshaping their networks to face different needs and strategies in foreign markets. In fact, future research may also explore how network ties may permit overcoming knowledge access and learning in the host country and with partners, reducing costs, speeding up local embeddedness, and improving economic and strategic performance in an overall manner.

Future research may evolve in a number of different paths. For instance, what is the composition of networks that better supports internationalization at different stages? I.e., how should networks aimed at firms that are looking for their first international experiences differ from those with a wide track record of foreign deals? How stable or unstable are networks? This is important to understand if network members tend to develop opportunistic behavior and as soon as they capture a certain benefit, i.e., whether they remain or leave the network. What is the ideal network configuration for supporting internationalization? A number of questions 
emerge from applying a network rationale to the study of internationalizing firms.

To conclude, network membership may prove to be a valuable distinctive factor and provide a competitive advantage. It seems reasonable to suggest that the degree of embeddedness in a network lowers the perceived psychic distance hazards of internationalizing firms. Results include better performance and improved odds of survival. For instance, foreign entry into countries of the former Soviet sphere of influence, where the economic and cultural realities are quite different from those found in other Western European countries, requires to investigate not only the degree of perceived psychic distance, but also how this distance and the associated hazards may be overcome by partnering with either local or other foreign firms.

As we begin to question again how far firms should go in their diversification efforts including geographic diversification -, other theories may be brought up to examine the actual implications and ways to deal with the increased risks. Focusing on core competences, as some firms do, is coherent with the configurations that may emerge from networked firms.

\section{REFERENCES}

ANDERSEN, O.; BUVIK, A. Firms' internationalization and alternative approaches to the international costumer/market selection. International Business Review, [S.1], v.11, n. 3, p. 347-363, June 2002.

ANDERSSON, U.; JOHANSON, J. International business enterprise. In: I. Bjorkman \& $\mathrm{M}$. Forsgren (Eds.), The nature of the international firm. New York: John Wiley, 1997. cap. 3. p. 33-49.

AULAKH, P.; KOTABE, M.; TEEGEN, H. Export strategies and performance of firms from emerging economies: Evidence from Brazil, Chile and México. Academy of Management Journal, New York, v. 43, n.3 p. 342-361, June 2000.
AXELSSON, B.; EASTON, G. Foreign market entry: the textbook versus the network view". In: EASTON, G.; AXELSSON, B. (Eds.). Industrial networks: a new view of reality, London, Routledge, 1992. cap. 12, p. 218-234.

BARNEY, J. Firm resources and sustained competitive advantage. Journal of Management, Norwell, v. 17, n. 1, p. 99-120, 1991.

BECKERMAN, W. Distance and the pattern of intra-European trade. The Review of Economics and Statistics, [S.1.], v. 28, p. 31-40, 1956.

BLANKENBURG, D.; ERIKSSON, K.; JOHANSON, J. Business networks and cooperation in international business relationships. Journal of International Business Studies, Newark: Basingstoke, v. 27, n. 5, p. 10031053, Dec. 1996.

BRADLEY, F.; MEYER, R.; GAO, Y. Use of supplier-customer relationships by SMEs to enter foreign markets. Industrial Marketing Management, New York, v. 35, n. 6, p. 652-665, Aug. 2006.

BROUTHERS, K.; HENNART, J. Boundaries of the firm: Insights from international entry mode research. Journal of Management, Norwell, v. 33, n. 3, p. 395-425, June 2007.

BUCKLEY, P.; CASSON, M. Models of the multinational enterprise. Journal of International Business Studies, Newark: Basingstoke, v. 29, n. 1, p. 21-44, Mar. 1998.

M. The future of the multinational enterprise. London: Homes $\&$ Meier, 1976.

CARLSON, S. How foreign is foreign trade: a problem in international business research. Uppsala: Uppsala University Press, 1975.

CAVUSGIL, S.; ZOU, S. Marketing strategyperformance relationship: An investigation of the 
empirical link in export market ventures. Journal of Marketing, Chicago, v. 58, n. 1, p. 1-21, 1994.

CHETTY, S.; BLANKENBURG, H. Internationalisation of small to medium-sized manufacturing firms: A network approach. International Business Review, [S.1.],v. 9, n.2, p. 77-93, Apr. 2000.

COOK, K.; EMERSON, R. Power, Equity and Commitment in Exchange Networks. American Sociological Review, Washington, v. 43, n. 6, p. 712-739, 1978.

DOW, D.; LARIMO, J. Challenging the conceptualization and measurement of distance and international experience in entry mode choice research. Journal of International Marketing, Chicago, v. 17, n. 2, p. 74-98, 2009.

DUNNING, J. Trade, location of economic activity and the MNE: A search for an eclectic approach. In: OHLIN, B.; HESSELBORN, P.; WIJKMAN,P. (Eds.) The international allocation of economic activity, London: Macmillan, 1977. cap. 9, p. 395-418.

DUNNING, J. International production and the multinational enterprise, London and Boston: Allen \& Unwin, 1981.

Multinational enterprises and the global economy. India: Addison-Wesley, 1995.

New Challenges for international business research: back to the future. Cheltenham: Edward Elgar, 2011.

- The eclectic paradigm of international production: A restatement and some possible extensions. Journal of International Business Studies, Newark: Basingstoke, v. 19, n. 1, p. 131, Mar. 1988.

. LUNDAN, S. Multinational enterprises and the global economy. 2nd ed. Cheltenham: Edward Elgar, 2008.
EASTON, G.; HAKANSSON, H. Markets as networks: Editorial introduction. International Journal of Research in Marketing, Amsterdam v. 13, n. 5, p. 407-413, Dec. 1996.

ELO, M. SME internationalisation from a network perspective. Abo Akademis Forlag-Abo: Akademi University Press, 2005.

EVANS, J.; MAVONDO, F. Psychic distance and organizational performance: An empirical examination of international retailing operations. Journal of International Business Studies, Newark: Basingstoke, v. 33, n. 3, p. 515-532, Sep. 2002.

; TREADGOLD, A.; MAVONDO, F. Explaining export development through psychic distance. International Marketing Review, Bradford, v. 17, n. 2, p. 164-168, 2000a.

Psychic distance and the performance of international retailers: a suggested theoretical framework. International Marketing Review, Bradford, v. 17, n. 4/5, p. 373391, 2000b.

FORD, D. Buyer/seller relationships in international industrial markets. Industrial Marketing Management, New York, v. 13, n. 2, p. 101-13, May 1984.

The development of buyer-seller relationships in industrial markets. European Journal of Marketing, Chicago, v. 14, n. 5/6, p. 339-354, 1980.

. et al. Managing business relationships: a network perspective. 2nd ed. Chichester: Wiley, 2003.

. et al. Managing networks. 18th ed. Perth, Australia: IMP Conference, 2002.

FURLAN, A.; GRANDINETTI, R.; CAMPAGNOLO, D. Local networks in global network: Is it possible?. The IMP Journal, [S.1.], v. 3, n. 3, 2009 .

R. bras. Gest. Neg., São Paulo, v. 14, n. 45, p. 438-452, out./dez. 2012 
GADDE, L-E.; FORD, D. Distribution research and the industrial network approach. IMP Journal, [S.1.], v. 2, n. 3, p. 36-52, 2008.

GHEMAWAT, P. Distance still matters: The hard reality of global expansion. Harvard Business Review, Boston, v. 79, n. 8, p. 137-147, Sept. 2001.

.Redefining global strategy: crossing borders in a world where differences still matter. Massachusetts: Harvard Business School Press, 2007.

GRIFFITH, D. Insights into gaining access to export financing: Understanding export lenders' ideal exporter profile. Journal of World Business, Oxford, v. 46, n. 1, p. 84-92, Jan. 2011.

GULATI, R.; NOHRIA, N.; ZAHEER, A. Strategic networks. Strategic Management Journal, Chichester, v. 21, n. 3, p. 203-215, Mar. 2000.

HÅKANSSON, H. International marketing and purchasing of industrial goods: an interaction approach. Chichester: Wiley, 1982.

; JOHANSON, J. A model of industrial networks: A new view of reality. In: AXELSSON, B.; EASTON, G. (Eds.). Industrial networks: a new view of reality. London: Routledge, 1992. p. 28-34.

; FORD, D. How should companies interact in business environments. Journal of Business Research, New York, v. 55, n. 2, p. 133139, Feb. 2002.

;JOHANSON, J. A model of industrial networks. Uppsala: University of Uppsala, , 1984.

;SNEHOTA, I. Developing relationships in business network. London: Routledge, 1995.

No business is an island: The network concept of business strategies. Scandinavian Journal of Management, Oxford, n. 22, n.3, p. 256-270, Sep. 2006.
HALLEN, L.; WIEDERSHEIM-PAUL, F. Psychic distance and buyer-seller interaction. In: BUCKLEY, P.; GHAURI, P. (Eds.) The internationalization of the firm: a reader. London: Harcourt. 1993. p. 291-302.

HARZING, A. W. The role of culture in entry mode studies: From neglect to myopia. In: HITT, JOSEPH CHENG and MICHAEL.Advances in International Management. Amsterdam: New York Elsevier/JAI, 2003.

HENNART, J.-F. A transaction costs theory of equity joint ventures. Strategic Management Journal, Chinchester, v. 9, n. 4, p. 361-374, July/ Aug. 1988.

.Down with MNE centric theories! Market entry and expansion as the bundling of MNE and local assets. Journal of International Business Studies, Newark: Basingstoke v. 40, n. 9, p. 1432-1454, Dec. 2009.

HITE, J.; HESTERLY, W. The evolution of firm networks: From emergence to early growth of the firm. Strategic Management Journal, Chinchester, v. 22, n. 3, p. 275-286, Mar. 2001.

HYMER, H. The international operations of national firms: a study of foreign direct investment. Cambridge, MA: MIT Press, 1976.

JOHANSON, J.; MATTSSON, J. Internationalisation in industrial systems: a network approach, in strategies in global competition. In: HOOD, N.; VAHLNE, J-E (Eds.). Strategies in global competition: New York: Croom Helm, 1998. cap. 8, p. 287-331.

.The internationalization process of the firm - A model of knowledge development and increasing foreign market commitments. Journal of International Business Studies, Newark: Basingstoke, v. 8, n. 1, p. 2332, Mar. 1977. 
.The mechanism of internationalisation. International Marketing Review, Bradford, v. 7, n. 4, p. 11-24, 1990.

.The Uppsala internationalisation process model revisited: from liability of foreignness to liability of outsidership. Journal of International Business Studies, Newark; Basingstoke, v. 40, n.9, p. 1411-1431, Dec. 2009.

Commitment and opportunity development in the internationalisation process: a note on the Uppsala internationalisation process model. Management International Review, Wiesbaden, v. 46, n. 2, p. 1-14, Mar. 2006.

; WIEDERSHEIM-PAUL, F. The internationalization of the firm: four Swedish cases. Journal of Management Studies, Oxford, v. 12, n. 3, p. 305-322, 1975.

KOGUT, B.; SINGH, H. The effect of national culture on the choice of entry mode. Journal of International Business Studies, Newark; Basingstoke, v. 19, n. 3, p. 411-432, Jan. 1988.

LEVITT, T. The globalization of markets. Harvard Business Review, Boston, v. 61, n. 3, p. 92-102, May-June, 1983.

MADSEN, T.; SERVAIS, P. The internationalization of born globals: An evolutionary perspective. International Business Review, [S.1.], v. 6, n.6, p. 561-583, Dec. 1997.

MAGNUSSON, P. et al. In cultural distance in international business: a meta-analytic review. In: ANNUAL MEETING OF THE ACADEMY OF INTERNATIONAL BUSINESS. 48., 2006, Beijing. AIB Annual conference, Beijing. Proceedings... Michigan: AIB, 2006. p. 1-32.

MINBAEVA, D. Knowledge transfer in multinational corporations. Management

International Review, Wiesbaden, v. 47, n. 4, p. 567-593, Oct. 2007.
NOHRIA, N.; GHOSHAL, S. The differentiated network. San Francisco: Jossey - Bass Publishers, 1997.

OVIATT, B.; MCDOUGALL, P. Toward a theory of international new ventures. Journal of International Business Studies, Newark: Basingstoke, v. 25, n. 1, p. 45-64, Mar. 1994.

PETERAF, M. The cornerstones of competitive advantage: a resource-based view. Strategic Management Journal, Chinchester, v. 14, n. 3, p. 179-191, Mar. 1993.

PORTER, M. Competitive strategy: techniques for analyzing industries and competitors. New York: The Free Press, 1980.

ROOT, F. Entry strategies for international markets. Lexington Books, New York, 1994.

RUGMAN, A. Inside the multinationals. New York: Columbia University Press, 1981.

SOUSA, C.; BRADLEY, F. Cultural distance and psychic distance: Refinements in conceptualisation and measurement. Journal of Marketing Management, London, v. 24, n. 5, p. 467- 488, 2008.

distance: Two peas in a pod? Journaf International Marketing. Chicago, v. 14, n. 1, p. 49-70, Mar. 2006.

TORNROOS, J-A. Internationalisation of the firm: a theoretical review with implications for business network research. In: INDUSTRIAL MARKETING AND PURCHASING CONFERENCE, 18., 2002, Dijon, France. Proceedings... [S.1.]: IMP Groupe, 2002. p.1-21.

Terminating relationships in business networks? Reflections on business strategy. In: INDUSTRIAL MARKETING AND PURCHASING CONFERENCE, 20., 2004, 
Copenhagen Dinamarca. Proceedings... [S.1.]: IMP Groupe, 2004. p. 1-17.

VERNON, R. International investment and international trade in the product cycle. Quarterly Journal of Economics, Cambridge, n. 80, n. 2, p. 190-207, May 1966.

WANG, P.; TONG, T.; KOH, C. An integrated model of knowledge transfer from MNC parent to China subsidiary. Journal of World Business, Oxford, v. 39, n. 2, p. 168-182, May 2004.

WEISFELDER, C. Internationalization and the multinational enterprise: development of a research tradition. Advances in International Marketing: reassessing the internationalization of the firm, [S.1.], v. 11, p. 13-46, 2001.
WELCH, D.; WELCH, L. The internationalization process and networks: a strategic management perspective. Journal of International Marketing, Chicago, v. 4, n. 3, p. 11-28, 1996.

WERNERFELT, B. A resource-based view of the firm. Strategic Management Journal, Chinchester, v. 5, n. 2, p. 171-180, Apr./June 1984.

ZHAO, H.; LUO, Y.; SUH, T. Transaction cost determinants and ownership-based entry mode choice: A meta-analytic review. Journal of International Business Studies, v. 35, n. 6, p. 524544, Nov. 2004.

ZOU, S.; TAYLOR, C.; OSLAND, G. The EXPERF scale: a cross-national generalized export performance measure. Journal of International Marketing, Chicago, v. 6, n. 3, p. 37-58, 1998. 